\title{
Simultaneous adsorption of chlordimeform and zinc on montmorillonite
}

\author{
Esmeralda Morillo and Celia Maqueda
}

Instituto de Recursos Naturales y Agrobiologia, Apartado 1052, 41080-Seville, Spain

\begin{abstract}
The competitive adsorption of the cationic pesticide chlordimeform and the heavy metal zinc on montmorillonite was studied. For different concentrations of $\mathrm{Zn}$ used, chlordimeform decreases (in relation to $\mathrm{Zn}$-free treatments) when the pesticide is adsorbed simultaneously with the metal, but increases when $\mathrm{Zn}$ is adsorbed previously to chlordimeform. When comparing the $K_{\mathrm{D}}$ values chlordimeform is shown to have a higher affinity for montmorillonite when there is a previous adsorption of $\mathrm{Zn}$ than with the simultaneous adsorption of $\mathrm{Zn}$ and the pesticide. The adsorption of $\mathrm{Zn}$ decreases when chlordimeform concentration increases, in both cases, when the metal is adsorbed simultaneously with the pesticide and when chlordimeform has been previously adsorbed to $\mathrm{Zn}$.
\end{abstract}

Key words: adsorption; pesticide; heavy metal; montmorillonite

\section{INTRODUCTION}

Phenomena of adsorption on clay minerals appear to be some of the most important factors affecting the behaviour and fate of pesticides in soils (Bailey and White, 1967; Mortland, 1975). At the same time the study of heavy metal reactions with the organic and mineral components of the colloidal fraction of soils has increased tremendously (Garcia Miragaya and Dávalos, 1986; Inskeep and Baham, 1983).

Although there are many works on the adsorption on clays of pesticides and heavy metals independently, little attention has been given to the phenomena which take place when both are present together. So, the aim of this paper is to contribute to the clarification of the competitive effects between the cationic pesticide chlordimeform and the heavy metal zinc when they are adsorbed on montmorillonite.

\section{MATERIALS AND METHODS}

The clay used was a montmorillonite from Arizona SAZ-1 (Van Olphen and Fripiat, 1979), supplied by the Clay Mineral Society. 
Technical grade chlordimeform ( $99 \%$ purity), supplied by Schering Agro, S.A., was used. This pesticide is soluble in water ( $50 \%$ by wt) and ionizes completely, giving the chlordimeform cation and chloride anion. The adsorption experiments were done in triplicate in $50-\mathrm{ml}$ polypropylene centrifuge tubes, by mixing $0.1 \mathrm{~g}$ of clay mineral with $0.01 \mathrm{~N} \mathrm{NaCl}$ solutions containing various concentrations of chlordimeform and/or $\mathrm{Zn}$. The samples were shaken for $24 \mathrm{~h}$ at $20 \pm 1{ }^{\circ} \mathrm{C}$. The chlordimeform and zinc adsorbed were calculated as the differences between their concentrations before and after equilibrium. The concentration of chlordimeform was determined spectrophotometrically at $240 \mathrm{~nm}$ and zinc by atomic absorption spectrometry (AAS). The inorganic cation $\mathrm{Ca}^{2+}$ released during chlordimeform or/and zinc adsorption was determined by AAS using a Perkin Elmer apparatus model 703 .

The successive adsorptions ( $\mathrm{Zn}$ after chlordimeform or vice versa) were made by mixing $0.1 \mathrm{~g}$ of clay mineral with $0.01 \mathrm{~N} \mathrm{NaCl}$ solutions containing various concentrations of chlordimeform or zinc. The samples were shaken for $24 \mathrm{~h}$ at $20 \pm 1^{\circ} \mathrm{C}$. After reaching equilibrium, the suspensions were centrifuged and the solid samples treated again with zinc, in the case of those previously treated with chlordimeform, or vice versa. The adsorption isotherms were obtained by plotting the amount of chlordimeform or $\mathrm{Zn}$ adsorbed $\mathrm{C}_{\mathrm{S}}(\mu \mathrm{mol} / \mathrm{g})$ versus the equilibrium concentration, $\mathrm{C}_{\mathrm{e}}(\mu \mathrm{mol} / \mathrm{l})$.

Chlordimeform and zinc concentration data are means of 3 replications. In the case of the pesticide the standard deviations range from 0.05 to 0.67 and in the case of the heavy metal from 0.08 to 0.46 .

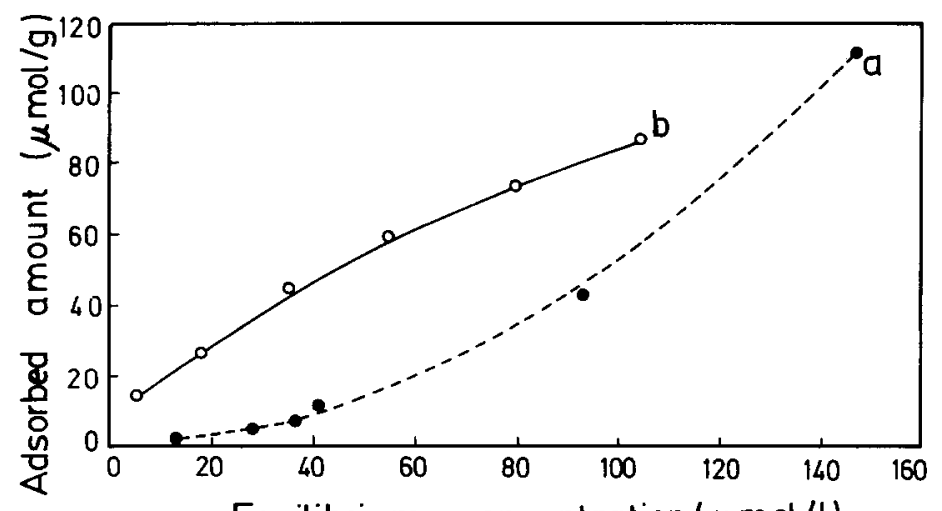

Equilibrium concentration $(\mu \mathrm{mol} / \mathrm{l})$

Fig. 1. Adsorption isotherms of chlordimeform (a) and $\mathrm{Zn}$ (b) on montmorillonite. 
The adsorption isotherms for the pesticide chlordimeform and the heavy metal zinc on montmorillonite are shown in Fig. 1. The adsorption isotherm of the pesticide (Fig. la) shows a shape corresponding to the ' $S$ ' type of Giles et al. (1960). One of the conditions for S-class curve indicates an increased affinity for the adsorbate after a few molecules have been adsorbed. The data of isotherms of other authors for the same pesticide and clay mineral (PérezRodríguez and Hermosín, 1979) contrast with those of this paper which showed adsorption isotherms of the conventional Langmuir type. This discrepancy can be attributed to the longer span of concentrations used by those authors, which masked the behaviour of the lower part of the isotherms. In addition in the previous paper no $\mathrm{NaCl}$ was added as background electrolyte, while in our case $0.01 \mathrm{~N} \mathrm{NaCl}$ solutions are added together with the different concentrations of chlordimeform. Thus for low concentrations of pesticide the principal process is the interchange of $\mathrm{Na}^{+}$from the background electrolyte, by $\mathrm{Ca}^{2+}$ cations which are saturating the planar positions on the montmorillonite and after that, the adsorption of chlordimeform by cationic exchange with $\mathrm{Na}^{+}$ions is favoured by higher concentrations, thus showing an increased affinity for the adsorbate. As was shown in previous papers (Maqueda et al., 1986), the adsorption of chlordimeform by the clay faction of soils takes place through a cationic exchange process.

Figure $1 \mathrm{~b}$ shows the adsorption isotherm of $\mathrm{Zn}$ on montmorillonite. It has been suggested by several authors (Benjamin and Leckie, 1981; GarciaMiragaya et al., 1986; Madrid et al., 1991) that sorption of metal ions by layer silicates and other adsorbents may occur at several types of surface sites, with higher energy sites acting at the lower range of surface coverages. Retention of $\mathrm{Zn}$ ions by montmorillonite can be expected to occur through two different processes: by adsorption on variable charge edge sites and by exchange of the exchangeable $\mathrm{Ca}$ ions saturating the permanent charge planar sites.

A useful and simple parameter to measure the affinity adsorbent-sorbate is the distribution coefficient, $K_{\mathrm{D}}$, which can be defined as

$K_{\mathrm{D}} M=\frac{(\text { Clay }-M)}{(\text { sol }-M)}$

Where (clay- $M$ ) is the concentration of sorbate $M$ ( $\mathrm{Zn}$ or chlordimeform) sorbed on the clay in mequiv./g and (sol- $M$ ) is the concentration of sorbate $M$ in the equilibrium solution in mequiv./g. This parameter has been used by several authors (Turner et al., 1984). In the case of $\mathrm{Zn}$, to calculate $K_{\mathrm{D}}$ it has been supposed that the metal is present in solution and may be on the clay as the $\mathrm{Zn}^{2+}$ and not as the $\mathrm{ZnOH}^{+}$species, since, taking into account 


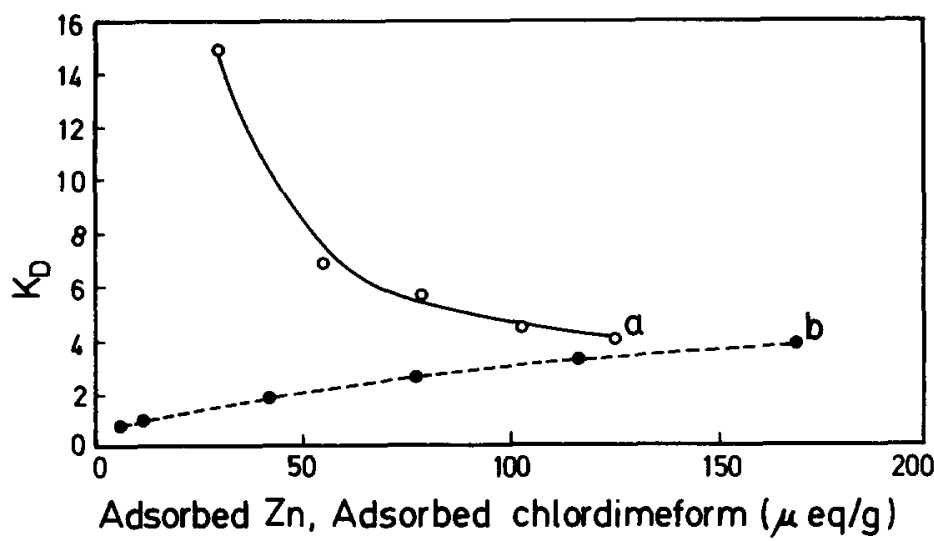

Fig. 2. Variation of the distribution coefficients $\left(K_{\mathrm{D}}\right)$ of $\mathrm{Zn}(\mathrm{a})$ and chlordimeform (b) with the amount of $\mathrm{Zn}$ or chlordimeform adsorbed, respectively.

the $\mathrm{pH}$ of our system (6.7) and the equilibrium constant for the reaction: $\mathrm{Zn}^{2+} \mathrm{H}_{2} \mathrm{O} \rightleftharpoons \mathrm{ZnOH}^{+}+\mathrm{H}^{+}, K=2.04 \times 10^{-8}$ ), the proportion of $\mathrm{Zn}^{2+}$ species is $90 \%$ in relation to $\mathrm{ZnOH}^{+}$.

It can be seen in Fig. $2 a$ that the system with a very low proportion of adsorbed $\mathrm{Zn}$ gives large $K_{\mathrm{D}}$ values, and when adsorbed $\mathrm{Zn}$ increases $K_{\mathrm{D}}$ undergoes a strong decrease towards reaching a more constant $K_{\mathrm{D}}$ value. As was mentioned above, large values of $K_{\mathrm{D}}$ for small amounts of $\mathrm{Zn}$ adsorbed may be a consequence of the existence of sites in the clay surface with high preference for this metal. On the other hand, Madrid et al. (1991) have observed that the number of high-preference sites for $\mathrm{Zn}$ on montmorillonite increases with $\mathrm{pH}$ and it is suggested that they are located in variable charge edge regions. The 'more constant' value of $K_{\mathrm{D}}$ when the amount of $\mathrm{Zn}$ adsorbed is high suggests that the other possible sites for $\mathrm{Zn}$ adsorption, that is, the planar exchange sites, have no special preference for this metal.

The plot of $K_{\mathrm{D}}$ values of chlordimeform vs surface pesticide loading for montmorillonite (Fig. 2b), shows a different behaviour from that observed for $\mathrm{Zn}$. It can be observed that if the chlordimeform sorbed on the clay is low, the $K_{\mathrm{D}}$ value is low and it increases as the sorbed pesticide is increasing. This seems to indicate that the adsorption of chlordimeform on montmorillonite takes place only through a cationic exchange process, in which the competition between the pesticide cations and the inorganic cations on permanent charge planar sites, and those from background electrolyte is very important. The fact that $K_{\mathrm{D}}$ value increases with the amount of chlordimeform adsorbed indicates that the sorbent-sorbate affinity increases, which is in agreement with the shape of the adsorption isotherm for this com- 
pound on montmorillonite (Fig. 1), since the ' $S$ '-type curve indicates an increased affinity for the adsorbate after a few molecules have been adsorbed. In this case the presence of some organic molecules on the planar positions of montmorillonite leads to a swelling of the interlamellar space of the clay facilitating an interchange between inorganic and organic cations.

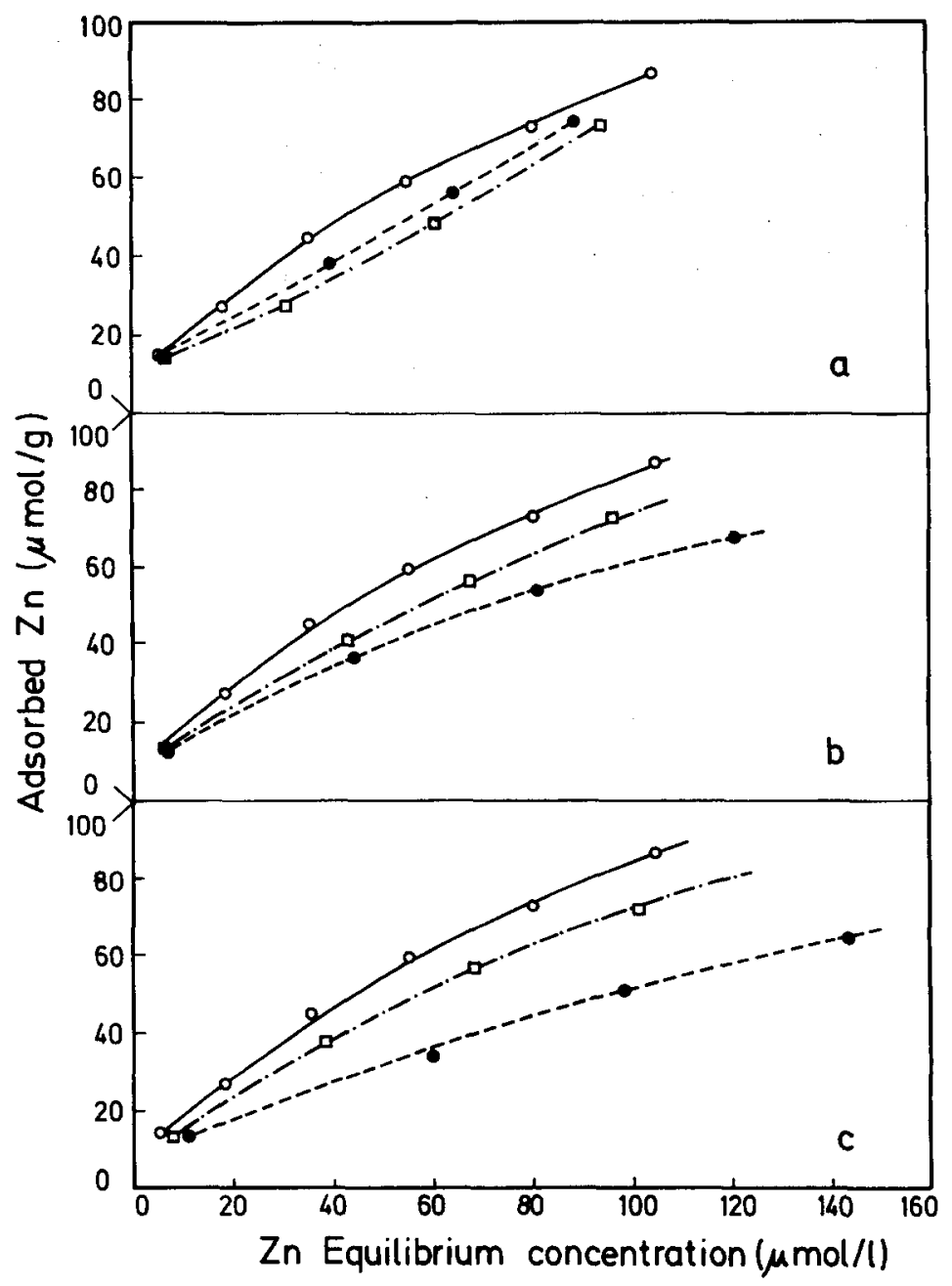

Fig. 3. Adsorption isotherms of $\mathrm{Zn}$ on montmorillonite from chlordimeform-free solutions ( $(0)$ in comparison with simultaneous $(\bullet)$ and successive (D) $\mathrm{Zn}$ adsorption, at various chlordimeform concentrations: 0.1 (a), 0.5 (b) and 1.0 (c) $\mathrm{mmol} / \mathrm{l}$. 
Reaction of montmorillonite with solutions of both adsorbates: $Z n$ and chlordimeform

(a) Simultaneous and successive adsorption of $\mathrm{Zn}$ in the presence of chlordimeform

Figure 3 shows the adsorption isotherms on montmorillonite of $\mathrm{Zn}$ from chlordimeform-free solutions in comparison with simultaneous and successive $\mathrm{Zn}$ adsorption when the concentrations of chlordimeform used were $0.1 \mathrm{mmol} / \mathrm{l}$ (Fig. 3a), $0.5 \mathrm{mmol} / \mathrm{l}$ (Fig. 3b) and $1.0 \mathrm{mmol} / \mathrm{l}$ (Fig. 3c). It can be seen that the adsorption of $\mathrm{Zn}$ decreases when chlordimeform concentration increases in both cases, that is, when the metal is adsorbed simultaneously with the pesticide and when chlordimeform is adsorbed before $\mathrm{Zn}$.

In the case of $\mathrm{Zn}$ adsorption on interlamellar positions of montmorillonite it can be due to competition between $\mathrm{Zn}$ and chlordimeform for those permanent charge positions; in the case of the $\mathrm{Zn}$ fraction adsorbed on the edges of the mineral variable charge surfaces $\mathrm{Zn}$ adsorption is more difficult due to physical adsorption of pesticide molecules on the external surfaces of montmorillonite (Pérez-Rodríguez and Hermosín, 1979) and so, the approach of $\mathrm{Zn}$ to the clay is impeded.

On the other hand, differences can be observed if $\mathrm{Zn}$ adsorption is in the simultaneous or successive form. In the case of a low chlordimeform concentration, $\mathrm{Zn}$ adsorption is higher in the simultaneous than in successive form (Fig. 3a); but if the chlordimeform concentration is high, more $\mathrm{Zn}$ is adsorbed in the successive than in simultaneous form (Fig. 3c). The possible reason may be that, if the pesticide concentration used is high, a greater part is adsorbed on planar positions in the clay, opening the layers and facilitating the subsequent penetration of $\mathrm{Zn}$. This behaviour is possible only in a range of concentrations of chlordimeform much lower than the cationic exchange capacity (CEC) of the mineral, and so a very small fraction of interlamellar positions are occupied by the pesticide, the other positions being available for $\mathrm{Zn}$ adsorption.

When chlordimeform concentration is low, a great part is adsorbed physically on the external surfaces of montmorillonite. Thus, the approach of $\mathrm{Zn}$ to the variable charge positions on the clay is not easy if the clay has been previously treated with the pesticide. But, if treatment is simultaneous with $\mathrm{Zn}$ and chlordimeform, the high affinity of $\mathrm{Zn}$ for superficial positions makes it the first species to occupy those positions. Therefore adsorption is higher than in the successive form.

The same behaviour is also observed in the differences of the $K_{\mathrm{D}}$ value of $\mathrm{Zn}$ adsorption on montmorillonite in the presence of chlordimeform (Fig. 4), in which $K_{\mathrm{D}}$ values have been graphically represented as a function of the amount of $\mathrm{Zn}$ adsorbed, in the cases of simultaneous (Fig. 4a) and successive 


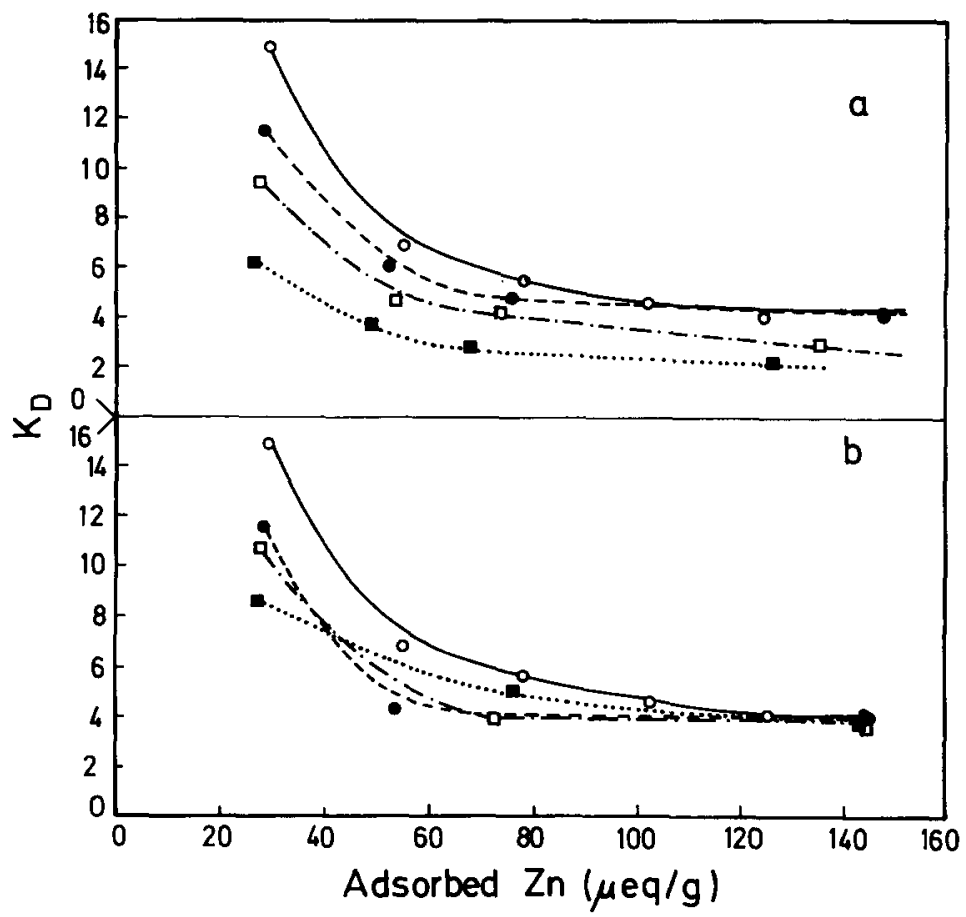

Fig. 4. $\mathrm{Zn} K_{\mathrm{D}}$ values as function of the amount of $\mathrm{Zn}$ adsorbed in simultaneous (a) and successive (b) adsorption, at various chlordimeform concentrations: $0(0), 0.1(\bullet), 0.5(\square)$ and $1.0(\square) \mathrm{mmol} / \mathrm{l}$.

adsorption (Fig. 4b). In both cases, a decrease in $K_{\mathrm{D}}$ value can be observed when chlordimeform concentration increases, so, $\mathrm{Zn}$ affinity for the clay decreases in the presence of chlordimeform.

In general, the $K_{\mathrm{D}}$ values obtained, over the whole ranges of chlordimeform concentrations used and amounts of $\mathrm{Zn}$ adsorbed, are lower in simultaneous than in successive adsorption, that is, the affinity of $\mathrm{Zn}$ for montmorillonite is higher in successive adsorption.

In simultaneous adsorption (Fig. 4a) the decrease in affinity is observed for both low and high amounts of $\mathrm{Zn}$ adsorbed. But, in successive adsorption (Fig. 4b) the behaviour of $K_{\mathrm{D}}$ curves is different in the case of high amounts of $\mathrm{Zn}$ adsorbed, since $\mathrm{K}_{\mathrm{D}}$ converges towards a constant value in each concentration of chlordimeform used. The reason may be that when the surface metal loading on the clay is high, the high affinity sites have been occupied, so only the interlamellar positions are accessible. In such conditions, when the adsorption is simultaneous, the chlordimeform concentration in the equilibrium solution provides strong competition for the $\mathrm{Zn}$, whose affinity decreases. But, in successive adsorption, the chlordimeform concentration 
present in equilibrium solution is very low, since there is only a small fraction of pesticide desorbed from the clay. The competition with $\mathrm{Zn}$ for adsorption is practically zero and the affinity of $\mathrm{Zn}$ for the planar surfaces is the same for all the concentrations of chlordimeform used previously, including when no chlordimeform had been used.

(b) Simultaneous and successive adsorption of chlordimeform in presence of $\mathrm{Zn}$ Figure 5 shows the adsorption isotherms on montmorillonite of chlor-

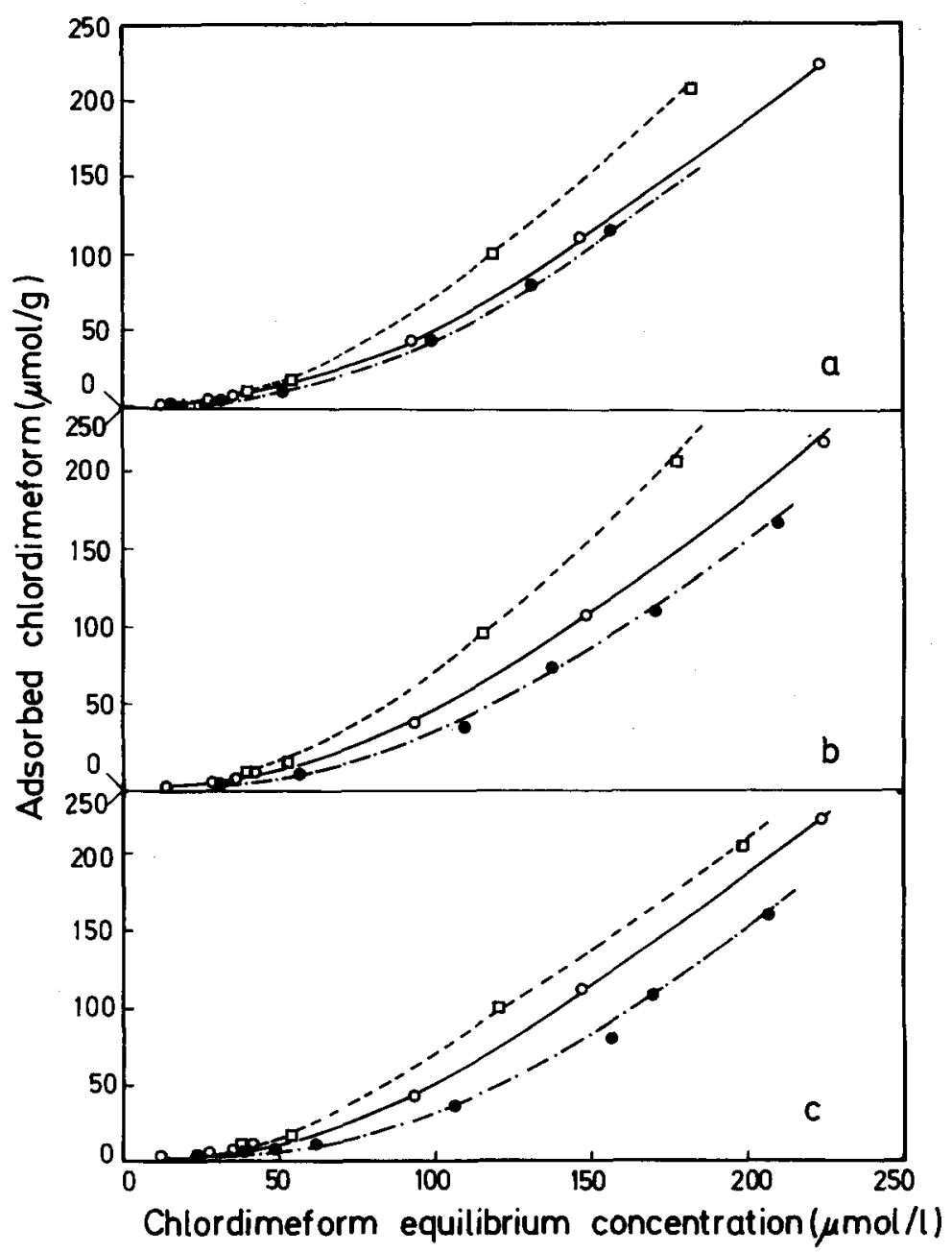

Fig. 5. Adsorption isotherms of chlordimeform on montmorillonite from $\mathrm{Zn}$-free solutions (O) in comparison with simultaneous $(\bullet)$ and successive $(\square)$ chlordimeform adsorption, at various $\mathrm{Zn}$ concentrations: 5 (a), 15 (b) and 30 (c) ppm. 
dimeform from $\mathrm{Zn}$-free solutions in comparison with simultaneous and successive chlordimeform adsorption when $\mathrm{Zn}$ concentration was $5 \mathrm{ppm}$ (Fig. 5a), 15 ppm (Fig. 5b) and $30 \mathrm{ppm}$ (Fig. 5c). For all concentrations of $\mathrm{Zn}$ used, chlordimeform adsorption decreases (in relation to $\mathrm{Zn}$-free treatments) when the pesticide is adsorbed simultaneously with the metal, but increases when $\mathrm{Zn}$ is adsorbed previously to chlordimeform. This may be due to the fact that the cationic exchange between chlordimeform and $\mathrm{Zn}$ adsorbed on planar positions is easier than between the pesticide and interlamellar calcium. Some experiments with $\mathrm{Zn}$-montmorillonite (not shown) indicate that the adsorption is higher than with $\mathrm{Ca}$-montmorillonite.

Figure 6 shows $K_{\mathrm{D}}$ values of chlordimeform adsorption on montmorillonite as a function of the amount of chlordimeform adsorbed in the cases of simultaneous (Fig. 6a) and successive adsorption (Fig. 6b).

In simultaneous adsorption, $K_{\mathrm{D}}$ values are very similar for each $\mathrm{Zn}$ concentration used and also to $K_{\mathrm{D}}$ values in the case of $\mathrm{Zn}$-free solutions; however, it can be observed that all the $K_{\mathrm{D}}$ curves of solutions containing

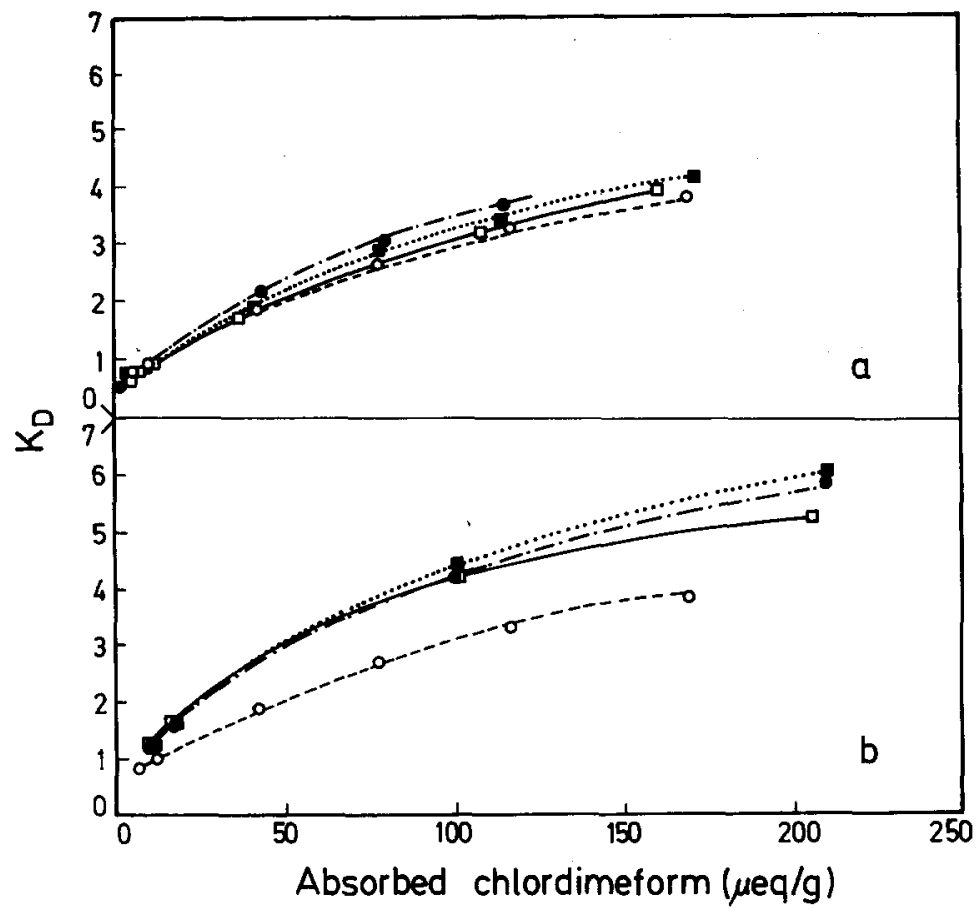

Fig. 6. Chlordimeform $K_{\mathrm{D}}$ values as function of the amount of chlordimeform adsorbed in simultaneous (a) and successive (b) adsorption, at various $\mathrm{Zn}$ concentrations: $0(0), 5(\bullet)$, $15(\square)$ and 30 (प) ppm. 
$\mathrm{Zn}$ are over those of $\mathrm{Zn}$-free solutions, so it can be concluded that in simultaneous adsorption of $\mathrm{Zn}$ and chlordimeform the affinity of chlordimeform for montmorillonite is very similar, but always a little higher, to the affinity without $\mathrm{Zn}$ in solution. This appears to contradict facts observed previously (Fig. 5.) where the absorption of chlordimeform, simultaneously with $\mathrm{Zn}$, is lower than its adsorption in $\mathrm{Zn}$-free solutions.

On the other hand, in successive adsorption of $\mathrm{Zn}$ and chlordimeform (Fig. 6b) a great difference can be seen between $K_{\mathrm{D}}$ values of chlordimeform adsorption corresponding to solutions with both adsorbates and those values corresponding to $\mathrm{Zn}$-free solutions, the former being higher than the latter. This is in agreement with the results observed in Fig. 5 showing the higher adsorption of chlordimeform for montmorillonite previously treated with $\mathrm{Zn}$ solutions.

Another interesting point to observe is that the affinity of chlordimeform for $\mathrm{Zn}$-treated montmorillonite is very similar for all the different $\mathrm{Zn}$ concentrations used, above all when the amount of chlordimeform adsorbed is low.

In conclusion, comparing the $K_{\mathrm{D}}$ values in Figs. $6 \mathrm{a}$ and $6 \mathrm{~b}$, a higher affinity of chlordimeform for montmorillonite is observed when there is a previous adsorption of $\mathrm{Zn}$, than in the simultaneous adsorption of $\mathrm{Zn}$ and the pesticide.

\section{REFERENCES}

Bailey, G.M. and J.L. White, 1967. Soil-pesticide relationship, adsorption and desorption of organic pesticides by soil colloids with implications concerning pesticide bioactivity. J. Agric. Food Chem., 12: 324-332.

Benjamin, M.M. and J.O. Leckie, 1981. Multiple-site adsorption of $\mathrm{Cd}, \mathrm{Cu}, \mathrm{Zn}$ and $\mathrm{Pb}$ on amorphus iron oxide. J. Colloid Interface Sci., 79: 209-221.

Garcia-Miragaya, J., R. Cárdenas and A.L. Page, 1986. Surface loading effect on Cd and Zn sorption by kaolinite and montmorillonite from low concentration solutions. Water Air Soil Pollut., 27: 181-190.

Garcia-Miragaya, J. and M. Dávalos, 1986. Sorption and desorption of $\mathrm{Zn}$ on Ca-kaolinite. Water Air Soil Pollut., 27: 217-224.

Giles, G.H., T.H. Mac Ewan, S.N. Nekhwa and D. Smith, 1960. Studies in adsorption: XI. A system of classification of solution adsorption isotherm and its use in diagnosis of adsorption mechanisms and measurement of specific surface area of solids. J. Chem. Soc., 3973-3993.

Inskeep, W.P. and J. Baham, 1983. Adsorption of Cd (II) and Cu (II) by Na-Montmorillonite at low surface coverage. Soil Sci. Sol. Am. J., 47: 660-665.

Madrid, L., E. Diaz-Barrientos and M.C. Contreras, 1991. Relationships between zinc and phosphate adsorption on montmorillonite and an iron oxyhydroxide. Aust. J. Soil Res. 29: 239-277.

Maqueda, C., J.L. Pérez-Rodríguez and M.P. Eugenio, 1986. Interaction of chlordimeform with the clay faction of a variable-charge. Soil Sci., 141: 138-143. 
Mortland, M.M., 1975. Interactions between clays and organic pollutants. In: S.W. Bailey (Ed.), Proc. Int. Clay Conf., Mexico City. Applied Publishing, Wilmette III, pp. 469-475. Pérez-Rodríguez, J.L. and M.C. Hermosín, 1979. Adsorption of chlordimeform by montmorillonite. In: M.M. Mortland and V.G. Farmer (Eds.), Proc. Int. Clay Conf. Oxford, 1978. Elsevier, Amsterdam, pp. 227-234.

Turner, M.A., L.T. Hendrickson and R.B. Corey, 1984. Use of chelating resin in metal adsorption studies. Soil Sci. Soc. Am. J., 48: 763-768.

Van Olphen, H. and J.J. Fripiat (Eds), 1979. Data Handbook for Clay Materials and other Non-metallic Minerals. Pergamon, Oxford. 